\title{
Effective Teacher Immediacy Behaviors Based on Students' Perceptions
}

\author{
Mehmet Akif Sözer \\ Faculty of Education, Gazi University, Turkey
}

Copyright $\mathrm{C} 2019$ by authors, all rights reserved. Authors agree that this article remains permanently open access under the terms of the Creative Commons Attribution License 4.0 International License

\begin{abstract}
The aim of this research is to determine effective teacher immediacy behaviors based on students' perceptions. The research is designed within descriptive survey model. The sample of this study was formed of via random sampling method, which covers 382 students from 5th, 6th, 7th and 8th grade from elementary schools. "Teacher Immediacy Behaviors Scale" which was developed by Crump (1996) and adapted by the researcher was used in the research in order to collect data. Research results show that out of twelve teacher immediacy behaviors, nine were found to be effective and important by students with "friendly smiling" ranked as the most effective and "physical appearance" as the least effective. The behaviors of "eye contact", "friendly smiling", and "personal examples" differed significantly in favor of male students according to gender variable. It can be observed from the result of this study that teachers' behaviors have impact on students.
\end{abstract}

Keywords Teacher Immediacy Behaviors, Verbal Immediacy Behaviors, Nonverbal Immediacy Behaviors

\section{Introduction}

In education, which is a communication process itself, in order to establish a positive relationship with his / her students, the teacher must be aware of his or her own behavior and the response of his / her students to this behavior. As teacher interacts with his/her students in the process of education, he/she has the first degree responsibility for the quality and efficiency of the interaction (Yılmaz, 1991). Teacher may fulfil this responsibility more efficiently by immediacy behaviors in the education process. The concept of teacher closeness was first described by Mehrabian (1969) as a behavior enhancing interpersonal nonverbal communication, and later, verbal communication that enhances the psychological closeness between the teacher and the students was added by Gorham (1988). Verbal and nonverbal positive behaviors of a teacher to his/her students during interaction process are defined as teacher immediacy behaviors (Geçer \& Deryakulu, 2004).

Verbal immediacy behaviors are used directly by teachers and they are important in developing pleasure or displeasure in students towards teachers. Verbal immediacy behaviors are the most rapidly developing ones between teacher and student (Christophel \& Gorham, 1995). These behaviors usually consist of humor, calling by name, giving personal examples and conveying experiences and encourage students to interact with teacher both inside and outside (Gorham, 1988). Researches show that there is a positive relationship between verbal immediacy behaviors and student motivation, cognitive-affective learning, and in addition, these behaviors encourage students to participate in classroom discussion (Gorham, 1988; Christophel, 1990; Menzel \& Carrell, 1999). A study including 319 college students and carried out by Cristophel and Gorham (1995) shows that verbal immediacy behaviors influence the perception of the whole class positively. According to Walker (2008), students feel themselves closer to teachers that communicate with students in person and give examples from their own lives.

Nonverbal immediacy behaviors are defined usually as implicit use of behavioral clues arousing affinity (Andersen, 1979). Nonverbal behaviors also called as body language are gesture and facial expressions, body movements and dress messages. Nonverbal teacher immediacy behaviors are defined as nodding positively, physical distance, power of voice expression, smiling, eye contact, relax body position, using gestures and facial expressions while speaking (Andersen, 1979). Moreover, treating friendly, toning voice, proper physical contact and spending time with students outside school are defined as nonverbal Immediacy clues (Neuliep, 1995; Sanders \& Wiseman, 1990).

It is known that gestures and facial expressions, body movements, clothing, personal care i.e. nonverbal behaviors done sometimes consciously and sometimes unconsciously are effective in education (Pektaş, 1988). 
At the end of the research that he carried out to find out how much body, voice and words influence communication, Albert Mehrabian concluded that body, voice and words are effective in proportion 55\%, 38\%, 7\% respectively. Ken Cooper did a research for same purpose and found out body, voice and words influence communication in proportion $60 \%, 30 \%, 10 \%$ respectively (Taşkın, 2012). These researches suggest that as opposed to general idea that words are more effective in communication, body language is more effective in communication. Being the most effective factor in communication, body language can be seen obviously in interaction between student and teacher. Teacher uses these three communication channels in classroom after starting communication. However, the importance of metalanguage and facial expressions aren't appreciated as enough as words.

There are different findings as to whether verbal or nonverbal teacher immediacy behaviors are more effective on learning outcomes. According to study carried out by Christophel (1990), nonverbal teacher affinity is more effective on learning compared to nonverbal teacher affinity. On the other hand, according to the researches of Christensen and Menzel (1998) and Frymier (1993), verbal teacher immediacy behaviors play an important role in student motivation. Study of Edwards and Edwards (2001) shows that there is a correlation between verbal and nonverbal affinity behaviors. In his study, which investigates teacher affinity behaviors based on student perception, Gorham (1988) found a significant relationship between verbal and nonverbal teacher behaviors, regardless of the type of message or the number of students in the class. Witt, Wheeles and Allen's (2004) meta-analysis study consisting of an analysis of 81 different studies dealing with relationship between teacher affinity and learning suggests similar results with studies measuring verbal teacher-directed behaviors when compared to surveyed perceived learning levels that measure non-verbal teacher behaviors. Research results suggest that in terms of perceived learning levels, there is a higher correlation between the studies analyzing verbal and nonverbal teacher immediacy behaviors. This study shows that using both verbal and nonverbal teacher immediacy behaviors together is more effective than using these behaviors separately.

Nonverbal affinity behaviors such as eye contact, smile, head movements, gesture and mimics and verbal affinity behaviors such as calling students by name, using humor, praising positive opinion and thoughts in the classroom activities have strong influence on students' affective, behavioral and cognitive learning areas and increase student motivation (İnceelli \& Candemir, 2016). As known, immediacy behaviors of teachers are one of the most important elements that influence success of communication process (Geçer \& Deryakulu, 2004). It is known that teacher affinity has an effect on students' affective (Andersen, 1979; Butland and Beebe, 1992; Christophel, 1990; Gorham,1988), behavioral (Christensen and Menzel, 1998) and cognitive learning areas (Lrfebvre and Allen, 2014) and also increase student motivation (Christensen and Menzel, 1988;Christophel and Gorham, 1995). Orpen (1994) investigated the relationship between teacher affinity and student learning, and found that the perceived teacher closeness among students influences cognitive learning, emotional learning and academic motivation, that is, motivated learners learn better than non-motived learners do. Christophel (1990), in his study, found that perception of teacher affinity has a high correlation with desired learning outcomes.

Analysis of the studies of teacher immediacy behaviors proved by studies carried out abroad to have positive effective on students' motivation, attitude and success shows that the studies dealing with verbal and nonverbal teacher immediacy behaviors aren't enough (Aktaş, 2007; Baş, 2010; Geçer and Deryakulu,2004; Kanmaz, 2008; Kolburan Geçer, 2002). Besides, studies support the idea that using verbal and nonverbal teacher immediacy behaviors together in communication process which increase teacher effectiveness. Thus, for our country, determining verbal and nonverbal teacher immediacy behaviors and how these behaviors are perceived by students is considered important for the efficiency of learning-teaching process.

This study was carried out in order to determine effective teacher immediacy behaviors based on student perception. For this purpose, answer are sought for the questions below.

1. What are effective teacher immediacy behaviors based on the perception of students from 5th, 6th, 7th and 8 th grade from elementary schools?

2. Is there a significant difference in effective teacher immediacy behaviors based on the perception of students from 5th, 6th, 7th and 8th grade from elementary schools according to gender variable?

\section{Method}

Descriptive survey model was used in this study the aim of which is to determine effective teacher immediacy behaviors based on the perception of students to reveal present situation.

\section{Population and Sample}

Population of the study consists of students from 5th, 6th, 7th and 8th grade from elementary schools of central provinces of Ankara.

The sample of the research consists of 382 students who are determined by " simple random sampling " method and study in the 5th, 6th, 7th and 8th grade of primary 
education. $35.1 \%$ of the sampled students are in the 5 th grade, $21.5 \%$ in the 6 th grade, $19.9 \%$ in the 7 th grade and $23.6 \%$ in the 8 th grade students. $52.6 \%$ of the students included in the study were female and $47.4 \%$ were male students.

\section{Data Collection Tool}

In order to determine effective teacher immediacy behaviors based on the individual perception of students, "Teacher immediacy behaviors scale" developed by Crump (1996) by using Gorham's (1998) studies as base and adapted by the researcher is used in the study. This assessment instrument measures eight nonverbal teacher immediacy behaviors of eye contact, gestures and facial expressions, physical appearance, friendly smiling, spending time outside classroom, voice toning, physical contact and physical intimacy and four verbal teacher immediacy behaviors of making a wisecrack, using the words" we and our", learning the names and giving personal examples.

Assessment instrument consists of 24 items with 12 positive and 12 negative ones. The negative ones are encoded reversely.

\section{Analysis of Data}

"Teacher immediacy behaviors scale" used in the study has a five-point likert type rating and it is rated as "Strongly Agree=1", "Agree=2", "Neutral=3", "Disagree =4", "Strongly Disagree =5". The evaluation intervals were calculated in order to interpret arithmetic average properly in accordance with five-point likert type. Score intervals of the scale are determined below.
Table 1. Score Intervals of Teacher Immediacy Behaviors Scale

\begin{tabular}{ccc}
\hline Ratings & Positive Items & Negative Items \\
\hline Strongly Agree & $1.00-1.80$ & $4.21-5.00$ \\
\hline Agree & $1.81-2.60$ & $3.41-4.20$ \\
\hline Neutral & $2.61-3.40$ & $2.61-3.40$ \\
\hline Disagree & $3.41-4.20$ & $1.81-2.60$ \\
\hline Strongly Disagree & $4.21-5.00$ & $1.00-1.80$ \\
\hline
\end{tabular}

Independent groups were t-tested to determine whether there was a significant difference between student perceptions of teacher immediacy behaviors according to gender variable. Significance level was taken as 0.05 .

\section{Results}

There are 24 items with 12 positive and 12 negative in "Teacher immediacy behaviors Scale" used with purpose to determine effective teacher immediacy behaviors based on student perceptions, so the averages of the answers to both positive and negative questions about the same behavior were taken together. For this reason, the scale was analysed over 12 items in total.

Distribution of arithmetic average and standard deviation that students got from "Teacher immediacy behaviors scale" is figured in Table 2 .

As Table 2 shows, most of the students express that teacher immediacy behaviors are effective and important. Out of twelve teacher immediacy behaviors, nine were answered as Strongly agree (1) and Agree (2) by students. According to Table 2 , students strongly agree with the item "friendly smiling" $\bar{X}=1.46)$. So it can be said that students feel at home when teachers behave friendly and smile in the classroom.

Table 2. Results of arithmetic average and standard deviation of Teacher immediacy behaviors Scale

\begin{tabular}{lcccc}
\hline \multicolumn{1}{c}{ Teacher immediacy behaviors } & $\overline{\boldsymbol{X}}$ & S.D. & Min. & Max \\
\hline Eye Contact & 2.04 & .87 & .50 & 5.00 \\
\hline $\begin{array}{l}\text { Speaking using gestures and facial } \\
\text { expressions }\end{array}$ & 2.40 & .88 & 1.00 & 5.00 \\
\hline Humor & 1.96 & 1.07 & .50 & 5.00 \\
\hline Friendly smiling & 1.46 & .77 & .50 & 5.00 \\
\hline Learning names & 2.69 & .99 & .50 & 5.00 \\
\hline Tone of voice & 2.44 & .91 & .50 & 5.00 \\
\hline Spending time outside of class & 2.25 & 1.00 & 1.00 & 5.00 \\
\hline Physical appearance & 3.01 & .83 & 1.00 & 5.00 \\
\hline Using the words "We and Our" & 2.01 & .91 & .50 & 5.00 \\
\hline Physical Contact & 2.10 & 1.05 & .50 & 5.00 \\
\hline Physical Intimacy & 2.89 & .87 & .50 & 5.00 \\
\hline Giving Personal Examples & 2.18 & 1.09 & .50 & 5.00 \\
\hline
\end{tabular}


The items "humor" $(\bar{X}=1.96)$, "Using the words "We and Our" $(\bar{X}=2.01)$,"eye contact" $(\bar{X}=2.04)$,"physical contact" $(\bar{X}=2.10)$, "giving personal examples" $(\bar{X}=2.18)$, "spending time outside the class" $(\bar{X}=2.25)$, "using gestures and facial expressions" $(\bar{X}=2.40)$ "toning voice" $\bar{X}=2.44)$ are rated positively by the students. According to these results, it is observed that students are willing to attend the class when teachers use humor, gestures and facial expressions. And they develop sense of belonging when teachers say "our class" and they become more cautious when teachers make an eye contact and they feel more comfortably when teachers touch them properly and they learn better when teachers give personal examples and spend time with them outside the classroom.

According to Table 2, students agree least with the items "physical appearance" $(\bar{X}=3.01)$, "physical intimacy" $\bar{X}=$ 2.89) "learning names" ( $\bar{X}=2.44)$. Therefore, it can be said that teachers' dressing formally, decreasing the gap between themselves and class and learning students' names don't increase students' interests for lesson. It is interesting that students don't agree with the item "physical intimacy" although it is supposed that teachers' moving in the classroom and being close to students will contribute to relationship between teacher and students.

Independent groups were t-tested to determine whether there was a significant difference between student perceptions of teacher immediacy behaviors according to gender variable. The results are pointed out in Table 3.

According to Table 3, eye contact, friendly smiling and giving personal examples differ at the rate of .05 based on gender variable. It is observed that eye contact item differs in favor of male students $[t(380)=-4.439, p<.05]$. So, it can be concluded that male students become more cautious than female students when teachers make an eye contact with them $\left(X_{\text {Female }}=1.85\right.$ ve $\left.X_{\text {Male }}=2.24\right)$. Also friendly smiling item differs significantly in favor of male students $[t(380)=-2.421, p<.05]$ which shows that male students feel more comfortable than female students when teachers behave friendly and smile in classroom $\left(X_{\text {Female }}=1.37\right.$ ve $X$ Male $=1.56$ ). In addition, it is observed that giving personal examples item differs significantly in favor of male students $[t(380)=-2.558, p<.05]$. Thus, it can be said that male students learn better than female students do when teachers give personal examples and spend time with them outside the classroom $\left(X_{\text {Female }}=2.05\right.$ ve $\left.X_{\text {Male }}=2.33\right)$. There aren't significant differences between other teacher immediacy behaviors based on gender variable

Table 3. Results of arithmetic average, standard deviation and t-test of teacher immediacy behaviors based on gender variable

\begin{tabular}{|c|c|c|c|c|c|c|c|}
\hline Teacher Immediacy Behaviors & $\begin{array}{c}\text { Success } \\
\text { Level }\end{array}$ & $\mathbf{N}$ & $\bar{X}$ & SD & sd & $\mathbf{t}$ & $\mathbf{p}$ \\
\hline \multirow{2}{*}{ Eye Contact } & Female & 201 & 1.85 & .803 & 380 & -4.439 & .000 \\
\hline & Male & 181 & 2.24 & .903 & 380 & & \\
\hline \multirow{2}{*}{$\begin{array}{l}\text { Speaking using gestures and facial } \\
\text { expressions }\end{array}$} & Female & 201 & 2.33 & .831 & 380 & -1.634 & .103 \\
\hline & Male & 181 & 2.48 & .931 & 380 & - & \\
\hline \multirow{2}{*}{ Humor } & Female & 201 & 1.95 & .998 & 380 & -.178 & .859 \\
\hline & Male & 181 & 1.97 & 1.162 & 380 & & \\
\hline \multirow{2}{*}{ Friendly smiling } & Female & 201 & 1.37 & .688 & 380 & -2.421 & .016 \\
\hline & Male & 181 & 1.56 & .851 & 380 & & \\
\hline \multirow{2}{*}{ Learning names } & Female & 201 & 2.71 & .960 & 380 & .524 & .600 \\
\hline & Male & 181 & 2.66 & 1.031 & 380 & & \\
\hline \multirow{2}{*}{ Toning Voice } & Female & 201 & 2.41 & .901 & 380 & -.750 & .454 \\
\hline & Male & 181 & 2.48 & .928 & 380 & & \\
\hline \multirow{2}{*}{ Spending time outside the classroom } & Female & 201 & 2.16 & .964 & 380 & -1.846 & .066 \\
\hline & Male & 181 & 2.35 & 1.038 & 380 & & \\
\hline \multirow{2}{*}{ Physical Appearance } & Female & 201 & 2.97 & .765 & 380 & -1.155 & .249 \\
\hline & Male & 181 & 3.07 & .911 & 380 & & \\
\hline \multirow{2}{*}{ Using the words "We and Our" } & Female & 201 & 1.95 & .898 & 380 & -1.338 & .182 \\
\hline & Male & 181 & 2.08 & .923 & 380 & & \\
\hline \multirow{2}{*}{ Physical Contact } & Female & 201 & 2.18 & 1.128 & 380 & 1.530 & .127 \\
\hline & Male & 181 & 2.02 & .952 & 380 & & \\
\hline \multirow{2}{*}{ Physical Intimacy } & Female & 201 & 2.89 & .858 & 380 & .067 & .947 \\
\hline & Male & 181 & 2.88 & .899 & 380 & & \\
\hline \multirow{2}{*}{ Giving Personal Examples } & Female & 201 & 2.05 & 1.070 & 380 & -2.558 & .011 \\
\hline & Male & 181 & 2.33 & 1.105 & 380 & & \\
\hline
\end{tabular}




\section{Argument}

In this study, effective teacher immediacy behaviors are analysed based on perception of $5^{\text {th }}, 6^{\text {th }}, 7^{\text {th }}$ and $8^{\text {th }}$ grade elementary school students. The results show that most of teacher immediacy behaviors increase teachers' efficiency. When analysing the most rated items, it can be observed that nonverbal Immediacy behaviors like friendly smiling, eye contact, physical contact, spending time outside classroom, using gestures and facial expressions and toning voice and verbal Immediacy behaviors like humor, using the words we and our, giving personal examples contribute to teacher efficiency. These findings suggest that teachers who use body language and have verbal communicative ability are considered more effective by students. In his study, Başer (2003) states that body language behaviors such as smiling, standing close and touching effects students positively. Crump's study (1996) in which he analyzes Immediacy teacher behaviors, it is observed that students rated humor, using gestures and facial expressions, toning voice and giving personal examples most. As opposed to these findings, "Effective Teacher Behaviors Based on Teacher Perceptions", the study of Şahin (2011) in which it is pointed out that teachers' using body language isn't effective in education, supports Çalışkan's study(2003) which shows that primary school teachers don't use gestures, facial expressions and body language enough. Student perception and teacher perception differ in terms of using body language effectively. According to teacher perception, since it isn't important to use body language in education, they don't pay attention to using it. On the other hand, students are in the opinion that teachers who use body language are more effective. This situation may result from their feeling more comfortably and expressing themselves better when they are with teachers they established a bond. It is thought that this may make their interest, attitude and motivation arise.

It is pointed out in the study that students agree least with the items "physical appearance", "physical intimacy" and "learning names". These results show that teachers' dressing formally, caring for appearance, moving in classroom and calling students by their names aren't considered important by students. Similarly, Crump's study (1996) suggests that "physical contact", "physical appearance" and "physical intimacy" are rated as the least agreeable teacher immediacy behaviors. In the study of Aktaş (2007), one of the most rated items in "Teacher Affinity Scale" was the item "My teacher makes me feel ashamed by calling my name loudly when I do something wrong." According to this result and result of this study, the reason of students' having negative attitude towards teachers that learn their names may result from the thought that students can be humiliated by these teachers.

It is concluded from the studies carried out in Turkey and abroad that teacher immediacy behaviors have a positive impact on teachers' efficiency (Cristophel, 1990;
Hürmeriç, 2008 Kanmaz, 2008; Mclemore \& Cunningham, 1994; Littlejohn, 2012; Richmond, 1990; Smith, 2011). According to Çalışkan and Yeşil (2005), nonverbal communication methods such as gestures and facial expressions, body movements and dressing that teachers use consciously or unconsciously are effective in education process and also body language plays an important role in drawing students' attention, embodying abstract expressions, emphasizing. There are studies that point out teachers Immediacy behaviors are in correlation with success and motivation of students. Studies of Geçer and Deryakulu (2004) and Aktaş (2007) suggest that there is a positive correlation between teacher affinity and motivation. According to the study of Velez and Cano (2008), especially nonverbal affinity behaviors increase students' motivation. In his study, Christophel (1990) points out that students of teachers who are considered as close to students have high motivation level of lesson. According to Cashin (1979), teacher immediacy behaviors play an important role on students' motivation. According to Gökçeli's (2013) research, teachers' using gestures and facial expressions effectively, making an eye contact and teaching lesson on foot are liked by students and create a good educational environment. Researches besides this study suggest that since students feel relaxed with smiling, humorous and friendly teachers, effective teacher immediacy behaviors are supposed to increase students' motivation. If teachers smile when they enter classroom, it will create a positive atmosphere. The way to train individuals to express themselves well is to create a positive class environment. This can be created only by teachers who are friendly, smiling and humorus and willing to communicate with students.

According to research findings, teacher immediacy behaviors of eye contact, friendly smiling and giving personal examples differ significantly in favor of male students. But there aren't significant differences between other teacher immediacy behaviors and gender. So, these findings suggest that male students' evaluation of their teachers are more positive compared to female students. Littlejohn (2012) analysed teacher immediacy behaviors based on perception of students and teachers and he found that teacher immediacy behaviors based on gender variable differed in favor of male students, which supports the findings of this study. It was concluded from Bağcl's (2008) study of secondary school students that ability of using body language effectively differs significantly according to gender. However, there is a different study belonging to Kolburan Geçer (2002) and suggesting that elementary school students' perception of teacher immediacy behaviors differs significantly in favor of female students. In his study, Başer (2003) found that female students are more influenced by teachers' facial expressions than male students and male students are influenced negatively by teachers' gestures. Çetinkaya (2011) reports that female students' opinions about communication abilities are more 
positive than male ones. There aren't significant differences between genders except few items favoring of female students as to use of body language by teachers in Kılıç's (2016) study. Kanmaz's (2008) study of 1st grade students from elementary school suggests that teacher immediacy behaviors based on gender variable differs significantly in favor of female students. In Aktaş's (2007) research, it is found that perceived teacher immediacy behaviors don't differ according to gender. So, it can be said that effective teacher immediacy behaviors are interpreted mostly differently by male and female students. It can be concluded from the literature that compared to male students, female students are influenced more positively by teacher immediacy behaviors. However, findings collected from this study don't support these results. It is thought that this situation may result from sample group or assessment instrument.

\section{Suggestions}

It can be observed from the result of this study that teachers' behaviors have impact on students. Since education and training are connected, teachers' behaviors as a role model for students are extremely effective on students. For this reason, teachers' teaching abilities must be increases via inService training to make them know themselves and realize how they are interpreted by their students.

According to the result of this study, "friendly smiling" and "humor" are rated most by students. Teachers should be informed about this and act more consciously.

\section{REFERENCES}

[1] Andersen, J. F. (1979). Teacher immediacy as a predictor of teacher etfectiveness. Communication yearbook 3 /543-559. New Brunswick, NJ: Transaction.

[2] Aktaş, G. (2007). Ortaöğretim öğrencilerinin algıladıkları ögretmen yakınlı̆̆ ile güdülenme düzeyleri arasında ilişki: Istanbul ili örneği, (Unpublished Master's Thesis). Yedi Tepe Üniversitesi, Sosyal Bilimler Enstitüsü, İstanbul.

[3] Bağc1, M. (2008). Öğretmenin beden dilinin öğrenciler tarafindan algılanması (Esenler ilçesi örneği, (Unpublished Master's Thesis). Beykent Üniversitesi, Sosyal Bilimler Enstitüsü, İstanbul.

[4] Başer, Ş. G. (2003). İlköğretim okullarında öğretmenlerin belirli beden dili davranışlarının 5. ve 8. Sinıf ögrencileri üzerindeki etkileri, (Unpublished Master's Thesis). Hacettepe Üniversitesi, Sosyal Bilimler Enstitüsü, Ankara.

[5] Cashin, W. E. (1979).IDEA technical report no. 1: Motivating students. Evaluation and Development. KS: Center for Faculty, Manhattan.

[6] Christensen, L. J. \& Menzel, K. E. (1998). The linear relationship between student reports of teacher immediacy behaviors and perceptions of state motivation and of cognitive, affective and behavioral learning. Communication Education, 4 (1), 82-90.

[7] Christophel, D. M. (1990). The relationship among teacher immediacy behaviors student motivation and learning. Communication Education, 39, 323-340

[8] Christophel, D. M.\&Gorham, J. (1995). A test-retest analysis of student motivation, teacher immediacy and perceived sources of motivation, and demotivation in college classes. Communication Education. Annandale.

[9] Frymier, A. B. (1993). The relationship among communication apprehension and immediacy on motivation to study. Communication Reports, 6, 8-17.

[10] Geçer, A. K. (2002). Öğretmen yakınlı̆ğnın öğrencilerin başarılarl, tutumlarl ve güdülenme düzeyleri üzerinde etkisi, (Unpublished Doctoral Thesis). Ankara Üniversitesi, Eğitim Bilimleri Enstitüsü. Ankara.

[11] Geçer, A., \& Deryakulu, D. (2004). Öğretmen yakınlığının öğrencilerin başarıları, tutumları ve güdülenme düzeyleri üzerindeki etkisi. Kuram ve Uygulamada Ĕ̈itim Yönetimi, (40), 518-543.

[12] Genç Gelişim .(2016). Eğitimde beden dilinin önemi. It was obtained from http://www.gencgelisim.com/v2/kategoriler/ 31-beden-dili/63-egitimde-beden-dilinin onemi.html on $04 / 08 / 2016$

[13] Gorham, J. (1988). The relationship between teacher immediacy behavior and student learning. Communication Education, 37, 40-53

[14] Kanmaz, F.(2008). İlköğretim birinci kademe öğrencilerinin başarılarında ögretmen yakınlık davranışlarını etkisi. (Unpublished Master's Thesis), Yedi Tepe Üniversitesi, Sosyal Bilimler Enstitüsü, İstanbul.

[15] Littlejohn, V. (2012). Student and teacher perceptions of teacher 1mmediacy behaviors and the influence of teacher 1mmediacy behaviors on student motivation to learn science. For The Degree Of Doctor Of Education, Gardner-Webb University School of Education,

[16] Mehrabain, A. (1969). Methods-designs: Same referents and measures of nonverbal behavior. Behavioral Research Methods and Instrumentation, 1, 203-207.

[17] Menzel, K. E., \& Carrell, L. J. (1999). The impact of gender and immediacy on willingness to talk and perceive learning. Communication Education, 48, 31-40.

[18] Pektaş, S. (1988). Sözel olmayan öğretmen davranışlarının ögretime etkilerinin değerlendirilmesi, (Unpublished Doctoral Thesis). Ankara Üniversitesi, Sosyal Bilimler Enstitüsü, Ankara

[19] Richmond, V. P. (1990). Communication in the classroom: Power and motivation. Communication Education, 39(2), 181-195.

[20] Smith, C. G. (2011). Middle school students' perceptions of teacher immediacy behaviors and their effect on motivation, (Unpublished Master's Thesis), Utah Valley University. USA.

[21] Taşkın, Ü.(2012). Iletişim becerisinin çatışma ĕgilimi ve 
algılanan ana baba tutumları ile ilişkisi, (Unpublished Master's Thesis). Ahi Evran Üniversitesi, Sosyal Bilimler Enstitüsü, Kırşehir.

[22] Walker, R. J. (2008). Twelve characteristics of an effective teacher: A longitudinal, qualitative, quasi-research study of in-service and pre-service teachers' opinions. Educational Horizons, 87, 61-68

[23] Witt, P., Wheeless, L.,\&Allen, M. (2004). A meta-analytical review of the relationship between teacher immediacy and student learning. Communication Monographs, 71, 161-183.

[24] Velez, J., J.\&Cano, J. (2008). The relationship between teacher immediacy and student motivation. Journal of Agricultural Education, 49-3. 